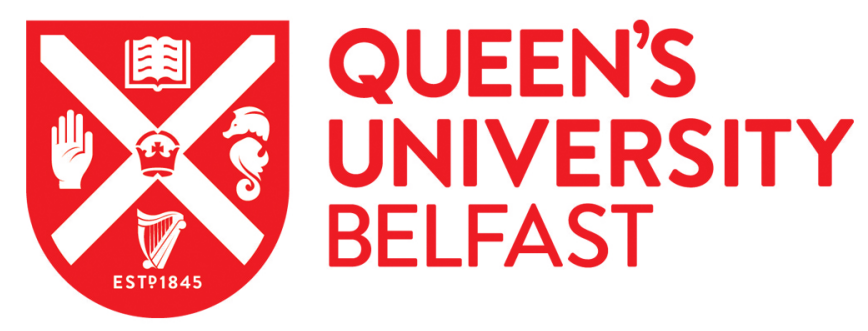

\title{
Planning, Platforms, Participation: City Resilience and Illegal Drugs in Belfast
}

Boland, P., Fox-Rogers, L., \& McKay, S. (2020). Planning, Platforms, Participation: City Resilience and Illegal Drugs in Belfast. International Planning Studies, 25(4), 320-339.

https://doi.org/10.1080/13563475.2019.1609431

\section{Published in:}

International Planning Studies

\section{Document Version:}

Peer reviewed version

\section{Queen's University Belfast - Research Portal:}

Link to publication record in Queen's University Belfast Research Portal

\section{Publisher rights}

( 2019 Informa UK Limited, trading as Taylor \& Francis Group. This work is made available online in accordance with the publisher's policies. Please refer to any applicable terms of use of the publisher.

\section{General rights}

Copyright for the publications made accessible via the Queen's University Belfast Research Portal is retained by the author(s) and / or other copyright owners and it is a condition of accessing these publications that users recognise and abide by the legal requirements associated with these rights.

Take down policy

The Research Portal is Queen's institutional repository that provides access to Queen's research output. Every effort has been made to ensure that content in the Research Portal does not infringe any person's rights, or applicable UK laws. If you discover content in the Research Portal that you believe breaches copyright or violates any law, please contact openaccess@qub.ac.uk. 


\section{PLANNING, PLATFORMS, PARTICIPATION: CITY RESILIENCE AND ILLEGAL DRUGS IN BELFAST}

\section{Introduction}

In recent years a 'wildfire of resilience' (Shaw, 2012) has swept across the public policy sector. The first point to make about resilience is that the concept is imbued with distinct air of positivity. For example, a 'confident rhetoric' abounds that is associated with resilience's ability to provide 'definitive responses' to the range of contemporary 'city ills' (Wilson \& Jonas, 2018); as such, “the idea behind resilience appears...remarkably 'intuitive' and attractive" (Béné et al, 2010: 45); moreover, as "a boundary object [it]...enable[s] multiple actors with differing values to share a common discourse" (Gillard, 2016: 15). Even trenchant critics acknowledge its "almost universal positive valance" (Leitner et al, 2018: 1278). However, planning academics question whether resilience is a 'promising' or 'problematic' concept when translated from the natural to the social world (Pizzo, 2015; Vale, 2014). Writing from a geographical perspective Welsh (2014: 17) warns of the "dangers and difficulties of translating theories and concepts between epistemic communities". Key concerns are rooted in the 'politics of resilience' and 'questions of power' regarding who scripts the agenda and who, what and where resilience is for (Chmutina et al, 2016); other prominent points of deliberation are the difficulties in 'operationalising resilience' (Meerow \& Newell, 2016) and 'fundamental problems' with measuring resilience (Martin \& Sunley, 2015); a final set of disputations relate to the tension between 'reframing resilience' toward a more 'transformatory' planning agenda (Davoudi, 2012) and its 'ideological fit' with neoliberalism (MacKinnon \& Derickson, 2013). Given this questioning context, we analyse a city embarking on its maiden resilience journey.

Like other cities around the world Belfast suffers from a range of common environmental, economic and social problems (e.g. flooding, unemployment and exclusion). However, the exceptionalism of Belfast, compared to say Bangkok or Boston, lies in the toxic fallout from its relatively recent violent socio-political history - 'the Troubles"1 - and subsequent sobriquet as a 'post-conflict city' (Murtagh, 2018). Illustratively, despite progress on peace and reconciliation it remains to a large extent deeply divided and socially segregated (Wilson, 2016). Beyond that, in this paper we show that illegal drugs are a 'chronic stress' not yet adequately analysed in relation

\footnotetext{
${ }^{1}$ Deep divisions between Nationalists and Unionists over religious-cultural identity and sovereignty (i.e. Catholic-Irish versus Protestant-British) led to 'the Troubles' (1968-1998) during which 3,600 people died as ethno-sectarian warfare raged between Republican and Loyalist paramilitaries. The former fought for a united Ireland (partitioned in 1921 following British colonial rule), the latter defended Northern Ireland's status within the UK.
} 
to the city's resiliency, and until this is properly problematised then Belfast's future Resilience Strategy will struggle to deliver genuine transformative change for the areas affected and those most marginalised. We are also concerned that a predictable policy agenda scripted by influential voices renders a pressing priority of the city's silent citizens unheard in Belfast's resilience debate. To address this democratic deficit we suggest sentiment platforms could prove to be a more effective participatory method for lending life to these 'lived experiences'. In so doing, this study offers a contribution to debates that examine "how the concept of resilience is interpreted and deployed" (Kythreotis \& Bristow, 2017: 5). In summary, the paper addresses three interrelated issues. Firstly, it problematizes the Belfast resilience agenda to show that a hugely significant 'chronic stress' (i.e. illegal drugs) is left unacknowledged and undebated; secondly, it connects the Belfast case with wider debates on the construction and implementation of resilience planning; finally, it offers some solutions to better incorporate the lived realities of ordinary people in local resilience debates.

\section{Case justification and method}

In May 2016 Belfast became the first city on the island of Ireland, and one of only five in the $\mathrm{UK}^{2}$, to join the Rockefeller 100 Resilient Cities (100RC) network. Since then the City Council has been preparing the groundwork for the construction of its inaugural Resilience Strategy. Most recently, in early 2018, Grainia Long was appointed as the city's first Resilience Commissioner. Her employment brief is to engage with and bring together local stakeholders, agencies, organisations and communities so that they contribute to the design and delivery of the Resilience Strategy. In light of this, resilience is very much a live issue and therefore timely for academic investigation. The research design for this paper has four components. First, we develop our line of argument through an engagement with academic literature from the natural and physical sciences (e.g. ecology, engineering and computing) and social sciences (e.g. city planning, human geography, political science and environmental studies). This provides a rich, transdisciplinary and coherent conceptual framing for the study, and generates interesting lines of empirical enquiry. Second, in terms of the policy context we scrutinise planning documents and resilience reports to ascertain what issues are ascribed significance and why and, arguably more importantly, what issues are not. Third, related to this, we attended a series of events organised by the City Council on the resilience challenges that allowed us to gauge how debates on resilience are being shaped, and who is scripting the agenda. Finally, in relation to data collection we conducted a detailed desk study of secondary sources. The first part involved accessing and analysing relevant social and economic

\footnotetext{
2 The others are Bristol, Glasgow, London and Manchester; Bangkok and Boston are also members.
} 
indicators from the Northern Ireland Statistics and Research Agency (NISRA) and Office for National Statistics (ONS) on employment, unemployment and inactivity. The second involved academic studies, media coverage (news and social) and official reports (e.g. State agencies and the police) on the impact of illegal drugs use, drugs economies, drugs paramilitarism and punishment attacks. In this context we are cognisant of the connectivities between "local communities and their surrounding ecosystems... [and] global scales" (Folke et al, 2010: 2), and "the processes and dynamics that affect people and/or their environments...occurring across scales (from local to global)" (Béné et al, 2010:12). Specifically this concerns how a massive global drugs trade connects to and has implications for local communities in Belfast (Boland et al, 2018). Collectively, these approaches reveal the factors that influence resilience thinking in Belfast, whilst enabling us to identify important issues not being discussed that should form part of the resilience debate.

\section{Theorising the 'wildfire of resilience'}

Around the world political leaders, policy makers, regeneration officers, economic strategists and spatial planners are responding to the so-called 'resilience turn' (Coaffee \& Clarke, 2015) and 'resilience renaissance' (Weichselgartner \& Kelman, 2015). The objective is to make cities resilient against extreme weather events, environmental disasters, terrorist attacks, climate change, energy crises, demographic shifts, economic downturns, medical emergencies, pandemic illnesses, social disruption and community chaos (Goldstein et al, 2015; Joseph, 2013; Moraci et al, 2018; Welsh, 2014; Wilson \& Jonas, 2018). Shaw (2012: 308) explains that resilience has effectively gone viral as "the term has not only spread like wildfire...it has been deployed by a wide range of decisionmakers, policy communities and non-State actors". Similarly, Leitner et al (2018: 1276) argue it "has developed a powerful momentum to become one of the most influential contemporary concepts influencing the thinking and actions of urban policy makers... across the globe". Tracing the genealogy and etymology of this fashionable, and increasingly formidable, concept reveals resilience has travelled from the natural and physical sciences to the social sciences, for example economic geography (Kakderi \& Tasopoulou, 2017; Martin, 2015), spatial planning (Béné et al, 2018; Deal et al, 2017) and even arts and cultural studies (Cooke, 2017; Pratt, 2017). Béné et al (2018: 4) trace resilience back to the 1940s and 1950s when "the concept emerged in psychology in the context of the negative effects of adverse life events such as exclusion, poverty, and traumatic stressors on vulnerable individuals and groups - in particular children". In subsequent decades it was further advanced in The notion of resilience originated in engineering and ecology to examine how 'systems' (e.g. objects, structures, flora and fauna) 'absorb/withstand' various 'shocks/stresses' (Folke, 2006; Holling, 1996). According to Holling (1996: 32), a prominent early 
commentator, "resilience of a system has been defined in two different ways". Engineering resilience refers to the ability of a system to 'bounce back' to a 'steady state' following a shock; here emphasis is placed on a speedy return to a stable equilibrium and retention of pre-shock structure. Ecological resilience is similar but also different in the sense that it focuses on a system's potential to 'absorb perturbation', the 'stability of a system' before any structural changes materialise and the possibilities for multiple equilibria (Folke, 2006; Holling, 1996, 2001).

In response to this 'static view of systems' (Davoudi, 2012) other approaches adopt evolutionary and social-ecological perspectives as resilience has 'migrated to the city' (Béné et al, 2012; Folke et al, 2010; Goldstein et al, 2015). Here the focus is on systemic unpredictability, uncertainty and chaos rather than returning to normality and equilibrium; from an economic geography reading authors contend that Capitalism, as a restless process, is a significant reason why economies and societies are subjected to regular periods of crisis and change (Martin \& Sunley, 2015; Pike et al, 2010). It also argued that social systems are more complex than those in the natural and physical world (Moraci et al, 2018). Central to the evolutionary perspective is the capability for 'positive adaptation and adaptability' in order to 'bounce forward' and deliver 'transformational resilience' (Bristow, 2010a; Simmie \& Martin, 2010). For example, the body of work on resilient economics (e.g. Christopherson et al, 2010; Dawley et al, 2010; Hudson, 2010; Martin, 2012; Shaw \& Maythorne, 2012) addresses how vulnerable economies react to and deal with endogenous and exogenous shocks and their variable powers of resistance and responsiveness. Specifically, the post-2008 global financial meltdown directed attention to "the differential and uneven ability of places to react, respond and cope with uncertain, volatile and rapid change" (Pike et al, 2010: 59). Given this place contingency and geographical unevenness the literature focuses on the 'determinants of resilience' and the need to building resilient economies that are less vulnerable and more responsive to external turbulence. One suggestion put forward is how sectoral diversity and economic heterogeneity can act as effective 'shock absorbers' against disruptive and damaging global forces (Kakderi \& Tasopoulou, 2017; Martin, 2012; Shaw \& Maythorne, 2012).

\section{Resilience planning}

Spatial planners have joined human geographers in shaping the resilience debate. Weichselgartner \& Kelman (2015: 249) explain “'resilience' has been replacing 'vulnerability' and 'sustainability' as a currency in academic and policy discourses and as a guiding principle in development planning”. To a large extent the professional planner's lexicon tracks the changing fashions within academia. Along with competitiveness (Bristow, 2010b), creativity (Florida, 2014) and culture (Boland et al, 
2016) resilience is now deeply embedded in planning discourses and practices on the futurity of the contemporary city. This is feeding a rapidly expanding body of work on resilience planning (e.g. Béné et al, 2018; Deal et al, 2017; Mehmood, 2016; Moraci et al, 2018; Sellberg et al, 2018; Shaw, 2012; Vale, 2014; Wilkinson, 2012). In developing 'resilience toolkits' (Coaffee \& Clarke, 2015; Welsh, 2014) planners have become focused on dealing with and responding to a range of social, economic, environmental and political 'risks/threats'. The aim is to use the planning system to ensure local areas can respond effectively to foreseen and unforeseen 'jolts/triggers/events' (e.g. flash flooding, traffic congestion, housing shortages, social disorder, economic recession and climate change). A particular priority is to enhance the 'adaptive capacity' of communities (Chmutina et al, 2016; Pizzo, 2015) and energise 'active citizens' (Beilin \& Wilkinson, 2015; Moon et al, 2017) - we will return to this shortly. Historically the equilibristic view has been influential through an implicit faith in a plan's capacity to facilitate 'bounce-back-ability' and 'return to normal', i.e. 'preserve what we have' and 'recover to where we were' (Davoudi, 2012). However, this default position fails to question what normality actually is and raises important normative and political questions; for example, returning to normality may not be an acceptable outcome for particular people, such as those disadvantaged, excluded and powerless (Goldstein et al, 2015; Porter \& Davoudi, 2012; Weichselgartner \& Kelman, 2015).

Thus, commentators contend that in order to transition a 'paradigm shift' beyond the equilibristic interpretation planning must be prepared for 'innovative transformation' (Davoudi, 2012; Porter \& Davoudi, 2012; Shaw, 2012). Here it is important for planners to focus on 'bouncing forward', not 'bouncing back' to equilibrium. As such there is an opportunity to 'reframe resilience' towards a more radical agenda that is genuinely transformational in embracing resistance to normality and listening to often unheard voices. Here public participation is crucial to an effective resilience planning process, particularly including 'underrepresented groups' and 'empowering people' (Gillard, 2016; Sellberg et al, 2018; Woodruff et al, 2018). In the same vein, Leitner et al (2018: 2180) refer to recognising and addressing the "needs of the most vulnerable". To achieve this, Fainstein (2018: 1271) suggests listening to and incorporating 'street science' on local issues claiming this 'local expertise' is as legitimate as that possessed by public officials. In this regard she calls for "resilience to encompass consideration of all aspects of urban life...[not] focus on a relatively limited spectrum of issues" (Ibid: 1272). However, Woodruff et al (2018) identify powerful "governance processes that script the resilient city vision". On this, Leitner et al (2018) highlight the strategically important role of global consulting firms (e.g. AECOM and Arup), working in collaboration with Rockefeller, who significantly shape a global discourse around 
resilience, that in turn penetrates the construction of local resilience debates. Given this, the danger is 'policy conservatism', maintaining the 'status quo', 'business as usual' and the construction of a 'new normality' (Chmutina et al, 2016; Fainstein, 2015; Meerow et al, 2016; Mehmood, 2015; Shaw \& Maythorne, 2012). Indeed, Bristow (2010a) is somewhat circumspect regarding whether resilience represents a genuine alternative to and/or something more than competitiveness - a 'hegemonic concept' in political, policy and planning circles since the 1990s. So the message is to 'tread carefully': "As the reframing of planning through a resilience lens gains currency, it is paramount that we continue asking critical questions" (Porter \& Davoudi, 2012: 333).

\section{'Critical questions': resilience planning, neoliberalism and smartness}

Davoudi (2012: 299) asks one such critical question: "Is resilience a promising concept for planning theory and practice?” Then Kythreotis \& Bristow (2017) ask why has resilience 'gained traction'; while Weichselgartner \& Kelman (2015) ask if it is the latest 'buzzword' and 'empty signifier' in the planner's dictionary. Although not dismissive of its promise, Vale (2014: 191) argues when "applied to cities, resilience is particularly problematic"; likewise, Pizzo (2015: 134) points to "problematiz[ing] the introduction of the concept of resilience into the planning domain". The first point to make is that although resilience has become 'extraordinarily popular' it is also 'ambiguous', 'banal', 'cloudy', 'contested', 'exploitable', 'fuzzy', 'nebulous', 'shallow', 'shibboleth', 'vague' and ultimately 'overused' (Beilin \& Wilkinson, 2015; Chmutina et al, 2016; Fainstein, 2015; Gillard, 2016; MacKinnon \& Derickson, 2013; Meerow et al, 2016; Mehmood, 2015; Moraci et al, 2018; Shaw \& Maythorne, 2012). Therefore, it can mean different things to different people. According to Davoudi (2012: 299) "it is not quite clear what resilience means, beyond the simple assumption that it is good to be resilient". This is the same criticism levied at the competitiveness discourse (Boland, 2014; Bristow, 2010b). Writing in the political science tradition Joseph (2013: 40,47) develops Davoudi's argument in claiming that resilience "lacks any proper philosophical meaning" and "does not really mean very much and whatever meaning it does have changes depending on the context". From an environmental standpoint Kaika (2017: 98) points to the politics lying behind the concept of resilience:

What is wrong with focusing on concepts like resilience...Namely, [the] concept...can only be allocated/handed down: from those in power to those in need. And as such, they fail - by design - to address questions related to the conditions that made it necessary for people and environments to seek resilience...in the first place. The best these practices can 
do is act as immunology: they vaccinate people and environments alike so that they are able to take larger doses of inequality and environmental degradation in the future.

Another line of critical questioning concerns resilience's 'ideological fit' with neoliberalism (Amin, 2013; Fainstein, 2018; Joseph 2013; Leitner et al, 2018; MacKinnon \& Derickson, 2013; Welsh, 2014; Wilson \& Jonas, 2018). The first point to make is that resilience is connected to the neoliberal language of 'urban survival' whereby in a global market place the policy and planning imperative is 'mobilise to compete' (i.e. become more resilient). As noted earlier, global organisations, consultancies and corporations "have taken the lead in spreading an urban resilience gospel that is perfectly attuned to neoliberal urbanism" (Leitner et al, 2018: 1281). A key element is the symbiotic link between resilience and the literature on smart cities. For Desouza \& Flanery (2013: 90): "It is imperative for cities to be resilient if they can be considered to be smart". Making connections to the subject matter of this journal Arafah \& Winarso (2017: 2) argue resilience is a "concept...which planners attempt to include as one of the factors or indicators in smart city planning". Similarly, Moraci et al (2018: 1) state: "Resilience is a concept included in the meaning of the smart city and is contemplated in the paradigm of smart planning”. Adopting a more sceptical tone Wiig \& Wyly (2016) speak of fetishizing 'cyborg urbanism' and 'electropolis' in recalibrating relationships between people, institutions, objects, places etc. (also Thrift, 2014) in the name of city resilience. Moreover, they and others (Barns, 2016; Brenner \& Theodore, 2002; Grossi \& Pianezzi, 2017; Peck \& Tickell, 2002) see the smart city discourse as another socio-spatial expression of neoliberal ideology and entrepreneurial governance that privileges the predatory role of software companies, private sector and business elites over the public good or citizen participation in decision making. Thus, for Grossi \& Pianezzi (2017: 84) within the smart city academic and policy community there is a need for "democratic debate about public interest" (see Boland et al, 2017; Lennon, 2017).

Next is the creation of 'entrepreneurial subjectivities' and the 'responsibilisation' agenda. For Joseph (2013: 41) resilience 'fits neatly' into 'new ontological commitments' whereby "to survive the uncertainties of complex systems, people have to show their own initiative as active and reflexive agents capable of adaptive behaviour". On this, Welsh (2014: 16) states the 'responsibilisation' agenda “produce[s] suitably prudent autonomous and entrepreneurial subjects in a world of naturalised uncertainty". This links to and sustains neoliberal forms of governmentality where the State exercises control 'at a distance' through charging individuals with a duty to 'govern themselves' (Joseph, 2013; Welsh, 2014). Furthermore, MacKinnon \& Derickson (2013) argue resilience is the neoliberal 'naturalistic metaphor' for the city that absolves capital and 
the State of culpability on the consequences resulting from economic turbulence; instead shifting responsibility onto communities and local people to better cope with unemployment, poverty and exclusion. Similarly, Welsh (2014: 16) speaks about the "potential depoliticising and postpolitical nature of the resilience discourse...[where] the resilience subject is conceived as resilient to the extent that it adapts to, rather than resists, the conditions of its suffering". Given this, critics claim neoliberalised resilience 'closes off' substantive material issues from proper debate and so undermines the scope for 'progressive change' for those areas and individuals adversely affected by debilitating forces (Amin, 2013; Joseph 2013; MacKinnon \& Derickson, 2013; Welsh, 2014). Given the concerns raised in this section, "a neoliberal use of resilience...must continuously be addressed" (Beilin \& Wilkinson, 2015: 1214).

Taking into account the parameters of the theoretical debate we have sketched out here, the 'critical question' that drives this paper is: to what extent is the Belfast resilience debate inclusive of the major 'stresses/triggers/threats' that exist within the city?

\section{Belfast's resilience journey}

The Rockefeller 100RC network was formed in 2013 and includes cities in different parts of the world, from Calgary to Chennai to Christchurch; Belfast was one of the final group of cities to be admitted three years later. The 100RC "mission is to catalyze a global resilience movement" and in pursuit of this "is dedicated to helping cities around the world become more resilient to the physical, social and economic challenges that are a growing part of the 21st century" (www.100resilientcities.org). To achieve this it highlights four key strategies (Goldstein et al, 2018). City Action to "create a holistic resilience strategy, and most importantly, implement it"; Resilience Solutions to "build a diverse network of global industry leaders and innovators from the private and non-profit sectors"; Local Leaders "must serve as resilience champions and experts, and galvanize support among stakeholders and residents"; and Global Influence "to inspire and influence global thought leaders, policy makers, and financial institutions to incentivize and fund resilience building" (www.100resilientcities.org). Each city is allocated $\$ 1$ million for developing a 'roadmap to resilience' that involves appointing a Chief Resilience Officer to lead the design and delivery of a 'robust' Resilience Strategy, in so doing obtaining support and assistance from a range of local stakeholders. The specific focus of 100RC is twofold. The first concerns 'sudden acute shocks' such as floods, earthquakes or terrorist attacks; t. The second relates to underlying “chronic stresses...that weaken the fabric of a city on a day-to-day or cyclical basis" (Leitner et al, 2018: 
1279). These include unemployment and endemic violence. As we will show these 'chronic stresses' are highly evident in Belfast and highly relevant to drugs.

Upon her confirmation in post Grainia Long stated:

The Belfast Agenda [Community Plan] sets out a number of ambitious economic and social goals for the next 25 years, and by working with the 100RC network, we can learn from many hard won practical programmes and initiatives to ensure delivery of these goals. The role provides an opportunity to showcase on a global scale, Belfast's story of growth and success as it has emerged from conflict (cited in Eichler, 2018).

Since 2016 Belfast City Council has embarked on its journey to lay the foundations for the Resilience Strategy. The first leg, facilitated by Arup consultants, involved a workshop to thrash out some of the key resilience challenges the city faces. In one sense, this event exemplifies how the concept of resilience has become an "integrating discourse that rallies an increasing number of people, institutions, and organisations under its banner" (Béné et al, 2010: 12). The document states:

On 15th November 2016 the 'Agenda Setting Workshop' for Belfast brought together a range of stakeholders to discuss the priorities for a resilient Belfast and to identify the key areas in which the Resilience Strategy and Commissioner for Resilience should focus. Around 80 key stakeholders from across the public, private and community/voluntary sectors contributed to the workshop (Belfast City Council, 2016: 3).

During this event Bryna Lipper, Chief Resilience Advisor and Senior Vice President of 100RC, explained it is important for cities to "maintain essential functions when threatened by acute shocks and chronic stresses"3. Reflecting the 'responsibilisation' agenda (after Joseph, 2013; Welsh, 3014) she stated that resilience is "the capacity of individuals, communities, institutions, businesses, and systems within a city to survive, adapt, and grow no matter what kinds of chronic stresses and acute shocks they experience". Reflecting the evolutionary perspective Lipper also spoke about the potential for cities to 'transform' after a shock and in so doing 'evolve' onto a new socioeconomic trajectory; in this sense "shocks and stresses can bring opportunities for cities". She then

\footnotetext{
3 These quotes, and others, are contemporaneous notes made by one of the authors who in attended the eventance.
} 
explained the City Resilience Framework (CRF) that has been rolled out amongst its members. As seen in Figure 1 there are ' 4 key dimensions': Health and Wellbeing, Leadership and Strategy, Economy and Society, Infrastructure and Environment; underpinning these are ' 12 drivers' that "collectively determine the city's ability to withstand a wide range of shocks and stresses". For this paper our interest rests within Health and Wellbeing (e.g. livelihoods and employment; public health services), Economy and Society (e.g. stability, security and justice; economic prosperity) and Leadership and Strategy (e.g. empowers a broad range of stakeholders).

Figure 1: City Resilience Framework

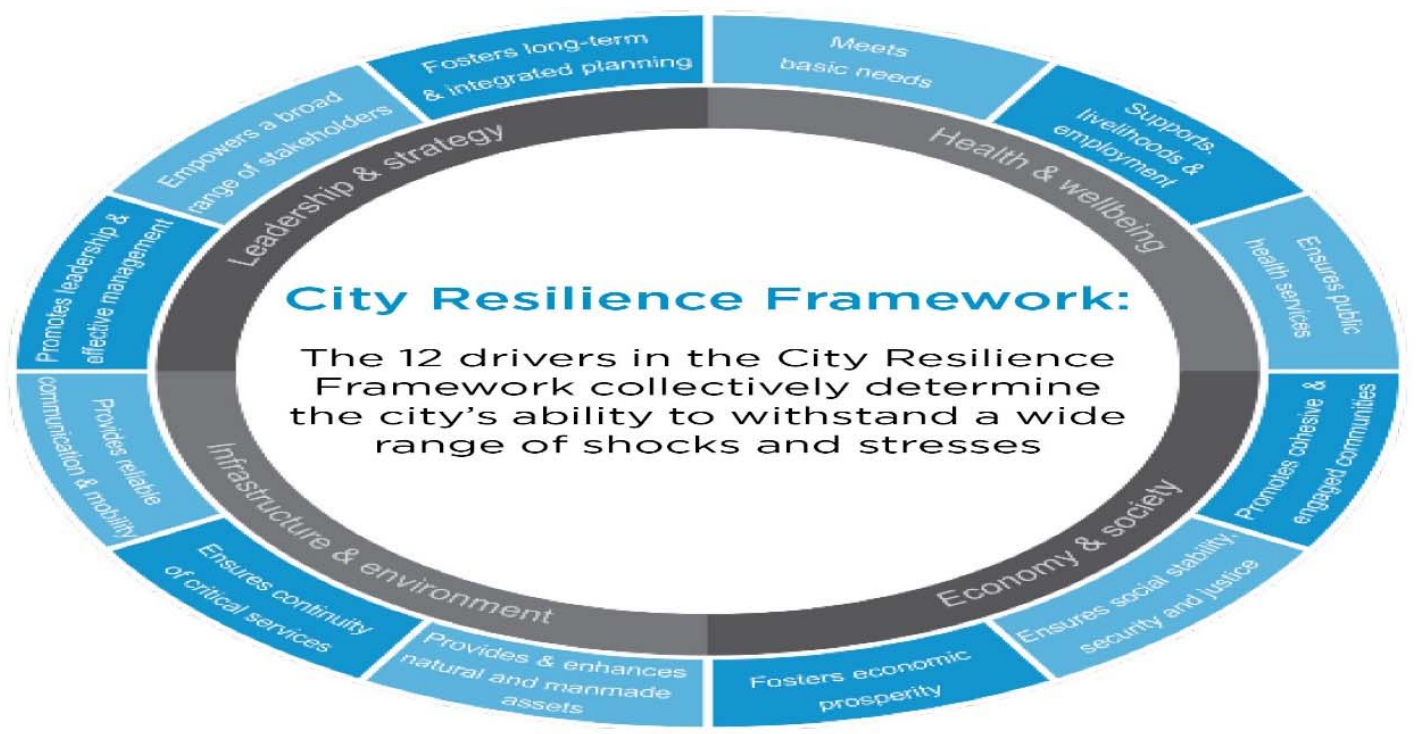

Source: Belfast City Council (2016).

Unsurprisingly, the document that emerged from this event reflects the prescriptive template set out by 100RC - reflecting Kitchin's (2014: 10) “one size fits all smart city in a box". As noted earlier Rockefeller and Arup collaborated to produce the CRF that is very popular with spatial planners and policy makers. This best practice tool "proves seductive, since it promises to address the complexities faced by cities in an increasingly interconnected and uncertain world" (Leitner et al, 2018: 1279). Belfast's 'resilience challenges' are: city economy underperforming in key areas; over dependence on public sector; complex city governance arrangements; ageing city infrastructure; widening inequalities in health, education and income; persistent deprivation in many neighbourhoods; and continued segregation and division that is restricting life opportunities (Belfast City Council, 2016). In addition to this, the 100RC website identifies several 'shocks and stresses': coastal and tidal flooding, cyber-attack, infrastructure failure, lack of social cohesion, political instability, riot and civil unrest and shifting macroeconomic trends (www.100resilientciti+es.org/cities/belfast/). We are extremely surprised that illegal drugs are not 
mentioned in this list given that they represent a 'chronic stress' that as we will shortly show 'weakens the fabric' of Belfast on a daily basis (after Leitner et al, 2018).

Earlier we mentioned the importance of public participation in resilience planning, of listening to 'underrepresented groups' (Woodruff et al, 2018), the 'needs of the vulnerable' (Leitner et al, 2018) and tapping into 'street science' and 'local expertise' (Fainstein, 2018). The underlying premise of which is 'empowering/engaging people' (Gillard, 2016; Sellberg et al, 2018). So we were interested in obtaining an attendee list for the Agenda Setting Workshop to assess the degree of inclusivity especially those hard-to-reach groups. Despite three attempts (via telephone and email) a Council respondent informed us: "I have an attendee list but unfortunately I don't have consent to sharing details" (Email communication, 30 ${ }^{\text {th }}$ April, 2018). We find this very surprising. Obviously we cannot make a definitive statement without access to the list. However, we argue that given the content and framing of the Agenda Setting Workshop and subsequent identification of issues we are confident those marginal voices who are subjected to the 'chronic stresses' associated with drugs were not in attendance. So with regard to the Leadership and Strategy cog in the CRF wheel we do not see evidence of 'empowering a broad range of stakeholders' and as such there remain questions over the level of genuine inclusivity.

We can validate our assertion because drugs were identified in The Belfast Conversation. This community consultation exercise interviewed 1,500 people via a residents' survey; in it they specifically identified 'drugs issues' as something they “don't like about Belfast” (Belfast City Council, 2015: 6, original emphasis). So local people's opinions on the negative consequences relating to drugs (see below) have been conveyed to the Council. Moreover, issues raised in The Belfast Conversation feed into The Belfast Agenda but very strangely 'drugs issues' do not feature in the Community Plan (Belfast City Council, 2017a); it is the same situation with regard to the Local Development Plan (Ibid, 2017b). We are perturbed that drugs have been identified as a significant socio-economic issue, read 'chronic stress', by the general public and yet they do not feature in the Community Plan, Local Development Plan or resilience debate. The next section sets out why we believe drugs to be a major resilience challenge blighting Belfast that ought to form part of the discussion on the Resilience Strategy.

\section{Drugs: health, economy, violence}

There are three areas in which drugs represent a significant resilience challenge for Belfast. Let us firstly consider the health dimension. Northern Ireland's drug problem emerged some time later 
than other parts of the UK (McElrath, 2004; McEvoy et al, 1998; McLaughlin et al, 2006; Silke, 1998). An important reason is that during 'the Troubles' Loyalist and Republican paramilitaries engaged in 'informal community policing' to control the activities that took place in their respective neighbourhoods. Thus, unlike other cities such as Liverpool or London during the 1970s and 1980s drugs importation, distribution and consumption was not an emergent or problematic issue in Belfast. However, the situation began to change from 1994 onwards following Loyalist and Republican paramilitary ceasefires, and it was at this time that serious drugs use began to develop. For example, in 1985 the number of registered heroin addicts in Northern Ireland was a mere 35 but in 2011 the number dramatically escalated to 1,500 (McElrath, 2004; Braden et al, 2011), a staggering increase of $525 \%$. This has prompted media commentators to speculate that a heroin epidemic' is gripping the capital city of Belfast (Magee, 2016; McDonald, 2016). In addition, the use of other recreational drugs has also become much more widespread. The latest Department of Health (2018: 5) report shows that in Northern Ireland during 2016-17 “4,368 clients presented to services for problem substance misuse". Of these, $27.4 \%(1,195)$ presented for misuse of drugs only while $28.6 \%(1,250)$ presented for drugs and alcohol misuse. Cannabis was the most commonly used drug at $65.8 \%$, followed by Cocaine $36.9 \%$, Benzodiazepines $35.1 \%$, Ecstasy 15.3\% and Heroin 10.9\%. Thus, the observation by McLaughlin et al (2006: 686) over a decade ago rings even more true today: "In a post-conflict situation, Northern Ireland has a growing illicit drug problem".

Another alarming observation is that addiction to and abuse of legal drugs, such as painkillers and sedatives, is actually causing more deaths than illegal drugs such as Heroin and Cocaine as underground markets for these prescription medications expand exponentially (BBC News NI, 2017a; O’Neill, 2017). According to NISRA (2017) there were 221 drug deaths across Northern Ireland in 2016: all Opioids 90, Cocaine 3, all Amphetamines 8, any psychoactive substances 7, all Benzodiazepines 65, all antidepressants 39, Pregabalin 8 and Paracetamol 1. Between 2002 and 2012 there were 906 drug related deaths in Northern Ireland (Belfast City Council, 2014); while between 2006 and 2016 there were 1,628 deaths: Opioids 633, Cocaine 46, all Amphetamines 52, any psychoactive substances 55, all Benzodiazepines 461, all antidepressants 303, Pregabalin 21 and Paracetamol 57 (NISRA, 2017a). Equally alarming is that in the first three weeks of 2018 seven suspected drug deaths were reported in Belfast (UTV, 2018).

Read in the language of health, it is clear that legal and illegal drugs (ab)use pose a 'chronic stress' that 'weakens the fabric' of Belfast on a daily basis (after Leitner et al, 2018). Most obviously these 
include the significant stresses inflicted upon their own lives by users and addicts (e.g. the ravages of addiction, mental and physical illness, prison and death); the significant stresses suffered by demented and/or bereaved family members; the significant stresses impacted on various elements of the public health and criminal justice systems; and the significant stresses (justified or not) related to growing concerns over exposure to drug paraphernalia (Boland et al, 2018). So in Belfast particularly and Northern Ireland more generally drugs are what Kaika (2017: 99) calls "living indicators, as signposts of what urgently needs to be addressed and where". A flavour of the level of community concern about drugs is captured below. It reveals clear evidence of how seriously marginal communities and public officials feel about the extent of the 'deep seated' drugs trade; given this, it is inconceivable that drugs do not represent a genuine and hugely significant 'chronic stress' in Belfast's resilience debate.

A church pastor urged the local community to "rise up to end this death trade in our midst" (McKee cited in Leonard, 2018). A senior police officer acknowledged the extent of the drugs problem:

Clearly there is an issue in Northern Ireland, it is a deep seated one, one that stretches across all of our communities, and for our part we're committed to working with the likes of the Public Health Agency, the Department of Health in order to do what we can to keep people safe (Singleton cited in UTV News, 2018).

A local activist expressed his exasperation at the lethal consequences:

It's a bad situation on the Shankill with the drugs. People are dicing with death, it is a real cocktail of death that they are taking...It makes me despair as a community worker, and it angers you (Pollock cited in Leonard, 2018).

Using equally emotive language a local councillor explained the severity of the situation:

The scourge of drug abuse has gripped communities across this city. There's no family left in Belfast that hasn't been touched by grief or trauma as a result of drugs. And it's getting worse. The scale of tragedy inflicted on this city by those dealing death on our streets is becoming overwhelming (McCusker cited in Scott, 2018).

The next issue concerns the economy. In the 1980s coal mining communities in England, Scotland and Wales were decimated by pit closers. Beatty \& Fothergill $(1998,2002)$ show these areas did not display high unemployment, rather the impact manifested in high economic inactivity as 
miners in areas with few or non-existent job opportunities were registered as long-term sick ${ }^{4}$. Thus, "substantial unemployment remains bidden, excluded from the official statistics" due to structurally weak local economies (Beatty et al, 2017: 5). Adapting this concept and applying to Belfast-; is argued that "in areas of high unemployment or high inactivity the drugs economy offers "hidden employment' in providing a source of activity and income" (Boland et al, 2018: 6). In disadvantaged communities extensive drugs economies with lucrative financial rewards draw in those unable to secure legal employment; drugs economies tend to be a largely but not exclusively working class phenomenon (on the UK see Johnson, 2012; on Brazil see Souza, 2005; on America see Massaro, 2015; on Mexico see Dooley, 2018). For example, in Northern Ireland during 2016-17 there were 5,546 drug seizures with an estimated street value of $£ 10.66$ million, in addition some $£ 1.7$ million of criminal assets were recovered by the police and customs officers (OCTF, 2018). With such huge sums of money involved it is understandable why the drugs trade is so attractive, especially to those unable to succeed in the formal economy.

In July 2018 Northern Ireland had the lowest employment rate of all twelve UK regions at 69.3\% compared to the national average of $75.5 \%$, conversely it had the highest economic inactivity rate at $27.7 \%$ compared to the national average of $21.2 \%$ (NISRA, 2018; ONS, 2018). Of those economically inactive $29 \%$ were sick/disabled; $28 \%$ were students; $24 \%$ were caring for family; $11 \%$ were retired; $9 \%$ formed the 'other' category. Some can be categorised as 'hidden unemployment' (after Beatty \& Fothergill, 1998, 2002) due to ongoing consequences of 'the Troubles" ${ }^{5}$. However, elsewhere it is suggested that "a proportion of these people and most evidently those who populate the $9 \%$ 'other' can be understood as 'hidden employment' due to involvement in the drugs economy" (Boland et al, 2018: 9). So the official indicators mask what is actually going on in labour markets across Northern Ireland and specifically Belfast. Indeed, 'hidden employment' can be read as a form of community resilience in revealing how certain local people cope with economic turbulence, i.e. 'shocks/jolts/triggers' such as structural decline, absence of investment and lack of jobs. Going back to an earlier point, drug dealers, somewhat ironically, reflect (albeit unintentionally) those 'entrepreneurial subjects' displaying the very 'adaptive behaviour' the resilience literature is accused of promoting (after Joseph, 2013; Welsh, 2014). Finally, within Economy and Society $\operatorname{cog}$ of the CRF drugs economics poses a different perspective on the resilience challenge relating to 'fostering economic prosperity'. For example, not formally recognising these alternative economic spaces as an important resilience challenge for

\footnotetext{
4 It is alse that Jiob-related pulmonary disorders were common.

${ }^{5}$ For example people suffering mental illness and physical disabilities as victims of paramilitary violence are now unable or unwilling to work in the formal economy and are placed on long-term sickness benefits (NISRA, 2017).
} 
the city is therefore fundamentally flawed; moreover, cognisance of these labour market dynamics would help the Council, in its own words, develop a better 'understanding of employability' (Belfast City Council, 2017c).

The final issue concerns violence. Historically, the Irish Republican Army (IRA) has been known for its anti-drugs stance ${ }^{6}$ (McElrath, 2004; Silke, 2000). Following ceasefires and decommissioning working class Nationalist areas are increasingly controlled by Direct Action Against Drugs and Republican Action Against Drugs ${ }^{7}$. The explicit brief of these Dissident Republicans ${ }^{8}$ is using 'extremis violence' (after Hudson, 2014) to remove the 'scourge of drug dealing' (Derry Journal, 2009; Monaghan, 2015). Both groups continue to punish ${ }^{9}$ and kill alleged drug dealers mainly but not singularly in Belfast and Derry. In another twist, during the last few years Belfast has witnessed assassinations of former Republican paramilitary associates connected directly and indirectly to the control of drugs space (Belfast Telegraph, 2015, 2016a; McDonald, 2013). Also, in late 2017 Communities Against Drugs in North Belfast publicly identified 48 drug dealers. In classic intimidatory style the alleged transgressors of social acceptability were ordered to 'bring themselves forward' or 'leave the area' (Fitzmaurice, 2017). However, there are also accusations that Dissident Republicans are involved in drug running. In August 2018 the police seized a large quantity of class A and B drugs (Cocaine, Cannabis and LSD) in West Belfast with an estimated street value of $£_{40,000}$ (McHugh, 2018). Then, in Newry a group called Saoradh were 'branded drug dealers' by the local police (Belfast Telegraph, 2018a). Media commentary such as this led a Unionist politician, Doug Beattie, to publicly question the activities of Dissident Republican anti-drugs gangs: "These individuals say they are trying to keep drugs off the streets...but in reality what they are actually doing is ensuring they have the lion's share of the drugs trade market" (cited in Belfast Telegraph, 2018b).

On the other side of the divide, the police and security forces believe that elements within Loyalist paramilitaries (Ulster Volunteer Force UVF, Ulster Defence Association UDA and Loyalist Volunteer Force LVF) have, since the 1990s, been heavily involved in the drugs trade (BBC News NI, 2017b; Gallaher \& Shirlow, 2006; McEvoy, McElrath \& Higgins, 1998). Indeed, it is claimed

\footnotetext{
${ }^{6}$ However, the smaller The Irish People's Liberation Organisation, an offshoot from the Irish National Liberation Army, was in the 1990s heavily involved in the drugs trade to fund their attacks on the British security services (Monaghan, 2004; Monaghan \&McLaughlin, 2006).

7 DAAD are active in Belfast while RAAD are mostly active in Derry/Londonderry which is Northern Ireland's second largest city; Catholics/Nationalists use the Irish name Derry while Protestants/Unionists use Londonderry reflecting their British identity.

8 Those who oppose the current peace process arrangements in Northern Ireland and the mainstream Republican politics of Sinn Féin - the largest Nationalist/Republican party.

9 These include attacks with baseball bats, iron bars, sledgehammers, electric drills and 'kneecappings'.
} 
that in the early 2000s a 'conflict of interests' over drugs led to deadly hostilities ${ }^{10}$ between the UDA and UVF in West Belfast (Monaghan, 2004; Monaghan \& McLaughlin, 2006). Similarly, as noted above during the last few years Belfast has witnessed assassinations of former Loyalist paramilitary associates connected directly and indirectly to the control of drugs space (BBC News NI, 2017c; Belfast Telegraph, 2016b; The Irish News, 2017). In addition, serious questions have been raised about the cosy relations ${ }^{11}$ between the Democratic Unionist Party (the largest unionist party in Northern Ireland) and the UDA who are "widely viewed as being involved in criminality, drug dealing, money laundering and extortion" (Barry, 2017: 51). Indeed, the negative public profile of Loyalist drugs activity came to a head in March 2018 when representatives of the UDA, UVF and Red Hand Commando appeared before the media, not for the first time, to state that any criminality, read drugs and violence, of their members would not be tolerated (Kearney, 2018).

Since the 1998 Good Friday Agreement there have been 158 security related deaths in Northern Ireland; strikingly, "the majority...were murders carried out by Republican and Loyalist paramilitaries, who mostly targeted victims within their own communities" (BBC News NI, 2018). During 2016-7 there were 94 casualties from shootings and assaults linked to Republicans and Loyalists, this represented a 30\% increase on 2015-6 and raised concerns over the physical and psychological impact, i.e. 'stress', on the victims many of whom deny any involvement in drugs activity (Dawson, 2017; McNeilly, 2017). Speaking to the media local commentator Paul Nolan explains: "The violence has been turned inwards...I think that we've had too easy an acceptance of paramilitarism and turned a blind eye too often" (cited BBC News NI, 2018). In an online report he elaborates:

In the lists of security related deaths no-one has been killed by a British soldier. No-one has been killed by a PSNI officer in security related circumstances. Instead the violence has been visited upon the victims by paramilitaries in quite an intimate way: they have been known personally by their killers; they have lived in the same neighbourhoods or worked in the same workplaces. In a very large number of cases the killers and the people who were killed had been comrades in the same paramilitary organisation (Nolan, 2018: np).

\footnotetext{
${ }^{10}$ Seven men were killed and several hundred Protestant families were forced out of their homes due to paramilitary intimidation.

${ }^{11}$ For example, public support from the UDA for the DUP at election time and reciprocal DUP support for funding to community organisations linked to the UDA. In addition, there are also serious reservations about "people who are "community workers' and officers in charitable and voluntary organisations by day, and drug-dealers and thugs by night” (Barry, 2017: 52).
} 
It is unquestionably true that drug feuds within Loyalism and Dissident 'Against Drugs' groupings are responsible for the overwhelming share of these deaths. Thus, "the perversity of drugs paramilitarism in Northern Ireland is that we now find Loyalists killing Loyalists and Republicans killing Republicans" (Boland et al, 2018: 10). Moreover, given the extent of brutal paramilitary punishments meted out to alleged drug dealers such incidents are regular front page news and headline stories on regional television. Thus, it would be ludicrous to claim that local stakeholders are unaware of violent drugs paramilitarism. Admittedly the history of 'sectarian violence' is briefly mentioned in the resilience workshop document; however, the words 'drug' or 'paramilitary' are not (Belfast City Council, 2016). We suggest this is part of the wider strategy designed to feed the narrative of a 'post-conflict' (Shirlow, 2006) or more accurately 'post-violent' city (Murtagh, 2018).

From a violence perspective it clear that drugs represent a 'chronic stress' that 'weakens the fabric' of Belfast on a daily basis (after Leitner et al, 2018). For example, within the Economy and Society cog of the CRF drugs violence poses a direct resilience challenge to creating 'cohesive communities' and ensuring 'social stability, security and justice'. It is clear that individuals, families and communities are terrorised and tormented by drugs gangs and paramilitary groups who implement their own form of violent restorative justice ranging from night time punishment attacks to broad daylight assassinations. Thus, it is evident that drugs are undoubtedly a huge 'chronic stress' for politicians, the police and planners (Boland et al, 2018) as they struggle to contend with escalating drugs related violence and entrenched community fear. So there are serious and ongoing challenges for city leaders, for the areas affected and ultimately the (occasionally innocent) people who suffer the consequences with disfigured limbs, compromised mobility and loss of life. Drugs violence is terrifying and traumatising and it is inconceivable that it does not feature in Belfast's resilience debate.

The fundamental question arising from the analysis is this. If the formal channels of public consultation are ineffective in registering drugs into the resilience debate, then what other mechanisms are available to enable local people can shed light on the 'chronic stresses' darkening their daily lives. It is this issue that we now turn our attention to.

\section{Possible avenues to be explored for the silent citizens: planning, platforms, participation}

This paper shows that illegal drugs are a major 'chronic stress' in Belfast. It also reveals the drugs problem has significant impacts, in terms of health, economy and violence, which warrant detailed consideration in the future Resilience Strategy. We claim the failure to include arises from a lack 
of proper engagement with those people and communities who are exposed to the drugs problem and/or a proper recognition of their suffering. On this Kaika (2017: 94) advises: "We need to focus on who has been silenced... and why. We need to erase assumptions of primacy, and listen to, and engage with, subjects beyond the usual suspects". Given this, we now discuss possible avenues for vocalising the voices of those silent citizens.

Current methods of participatory planning "fail to make citizens aware of opportunities for involvement" and are 'unsuitable or unwieldy' for certain sections of society (Wilson et al, 2017: 6). Public meetings and consultation exercises are seen as remote, tokenistic, ineffectual and even pointless, and there are tensions between (select) professional experts and (multiple) community voices. For Goldstein et al (2015: 1286) this necessitates more 'inclusive planning approaches' to "enable people to tell stories of what change means to them". Returning to an earlier point, on resilience planning Moraci et al $(2018: 2,14)$ speak of the 'participation of citizen groups' and a 'bottom up approach' that is sensitised to the 'needs of the population'. For them: "Engaging local communities in city planning is vital in building a society that can sustain resilience consistently...[and] best practice... requires intensive cooperation, public awareness and citizens' engagement" (Ibid, 2018: 16). On this, Davoudi states: "Listening to the silent voices requires more proactive and imaginative ways of engaging with people...formal procedures of planning...disregard...the value of people's everyday life experiences" (cited by Cooper, 2017: 2930). As we have noted during a community consultation exercise Belfast residents communicated to the Council that 'drugs issues' are a pressing problem that needs to be tackled. However, drugs do not feature in the Community Plan, Local Development Plan or resilience debate. We see this as evidence of "little sign of a profound engagement with a politics of resilience as a means for conceiving of change" (Welsh, 2014: 20). In Belfast, it is therefore important to enable resilience planning to capture a fuller range of voices and fuller range of 'stresses/shocks' (after Beilin \& Wilkinson, 2015; Coaffee \& Clarke, 2015; Goldstein et al, 2015). Then it is possible to grapple with the 'dark side of resilience' (Weichselgartner \& Kelman, 2015) to capture the fuller range of ordinary people's often difficult 'lived experiences', in this case the 'chronic stresses' associated with drugs, thereby ensuring those often unheard voices, or silent, and in many ways scared, citizens, are adequately addressed. The 'critical question' is how this can be achieved.

Recent interventions in the planning literature explore the 'role of technology' (e.g. sentience, apps, platforms etc.) to enhance public participation, empower citizens and generate, manage and present new forms of usable data (Deal et al, 2017). Wilson et al (2017: 14) argue "further work is 
required to see how technology could be embedded within established local planning practices". Their contribution is a pilot study of a smart watch app in the North East of England designed to 'support citizen feedback' on planning issues. ChangeExplorer affords local people the ability to contribute to decision making through a simplified interface rather than the complex use of GIS. The benefits are a more user-friendly engagement process and democratisation of planning (i.e. 'open, up-stream' discussion of local issues) that does not "favour selective consultation opportunities" (Ibid, 2017: 6). A crucial requirement is buy-in from key stakeholders, especially local authorities, to "legitimise a real-world use for the platform" (Ibid, 2017: 6). Relatedly, Barns (2016: 555) examines open data ${ }^{12}$ platforms and 'smartphone-equipped smart citizens' who are able to access and interact with various datasets (e.g. on local government services and decision making), allegedly leading to "greater citizen engagement and transparency of public institutions" (also Kitchin, 2014). This has led certain cities ${ }^{13}$ to develop "city-wide digital strategies that have clearly positioned open data initiatives in the context of a competitive urban landscape" (Barns, 2016: 560). However, Barns (2016: 565, 566) also cautions that open data programmes can be "skewed towards the interests of software entrepreneurs" with a "relatively poor conception of the public benefits". Thus, there can be a conflict between commercial and citizen interests on access to/use of open data; also 'digital entrepreneurialism' can result in a diminution of 'substantive citizen engagement'.

Also writing about citizen engagement Deal et al (2017) examine the possibilities of sentient planning. Debate on the 'sentient city' is focused on the management and analysis of big data through information and communication technologies (termed 'ubiquitous computing') in order to map, understand, monitor and inform the future use of cityspaces (Crang \& Graham, 2007; Kitchin, 2014; Shepard, 2009; Thrift, 2014). For Shepard (2009, np) the “"sentient' city is envisioned as being capable of reflexively monitoring our behavior within it and becoming an active agent in the organization of our daily lives”. A cautious Kitchin (2014: 9) claims sentience can lapse into "technological solutions [that] on their own are not going to solve the deep rooted structural problems in cities as they do not address their root causes". Deal et al (2017: 30) describe sentient planning as the "ability to collect, process, learn, contextualize, and present locally significant information". It is important to note that big data already exists on various drugs issues at a global, national, regional and local level, for example on drug seizures, commodity pricing, criminal gangs, number of addicts, number of convictions and number of deaths (Abramsky \& Drew, 2014;

\footnotetext{
12 Public or private data in a 'machine-readable' format that can be accessed without restriction.

13 Such as New York, Dublin, Manchester, Brisbane, Chicago.
} 
NISRA, 2017; OCTF, 2018; PSNI, 2017; UNODC, 2018). For obvious reasons other aspects of this clandestine economy are notoriously difficult to access and analyse, such as precise data on drugs users, drug dealers, drug revenues, money laundering and links between illegal and legal economies. Data does exist but it is largely speculative (Hall, 2012; Hudson, 2014).

Connecting back to an earlier discussion, Deal et al (2017: 33) refer to 'smart information systems' that ensure big data information becomes 'useful', 'user-friendly' and 'easy to interpret' for individuals involved in the planning process; allowing planners and others to effectively "understand, manage and plan complex urban systems". Assessing different sentient systems they highlight devices that capture 'users' perceptions' and 'cooperate with users' and the need to 'develop prototype services' for citizen engagement. Kaika (2017: 96) suggests that "instead of asking the usual interlocutors to refine the usual..."resilience" indicators, we actually took seriously...citizens and communities". One such computational technique for these issues is sentiment analysis. Vinodhini \& Chandrasekaran (2012: 282) state "sentiment analysis is a type of natural language processing for tracking the mood of the public". It is used to study people's emotions, feelings and perceptions, it is a form of 'text/opinion mining' to excavate how groups of people think on certain issues using comments, reviews and tweets. This is an example of what Kitchin (2014: 4) terms 'volunteered data' which "can provide useful insights into urban systems and city lives". Yu et al (2018) identify categorical and dimensional approaches to sentiment analysis. The former uses discreet classes of 'affective states' (positive, neutral, negative) plus six emotions (anger, happiness, fear, sadness, disgust and surprise) that are teased out from social media (e.g. Facebook, Twitter, blogs etc.) The latter uses mathematical tools to generate percentage scores teasing out 'degrees of emotions'. Thus, for Vinodhini \& Chandrasekaran (2012: 288) "sentiment detection has a wide variety of applications in information systems...and real time applications", and has emerged as an important sub-field of information management on the 'similarities and polarities' of public opinion. Reinforcing this point, Cooper (2017:30) argues: "Possibly the biggest barrier is access to accurate up-to-date data...Facebook has better data about the opinions of the population...There's much to be learned from social media".

It is true that Belfast is focused on digital technology and big data initiatives: "The Smart Belfast framework is about harnessing innovation, technology and data science to contribute to the success of the Belfast Agenda" (Belfast City Council, 2017c: 6). We suggest sentiment analysis can offer, using the Council's own words, "opportunities in digital and data technologies that can improve outcomes for citizens", and provide an "effective method and communication" for 
“collecting users' feedback" (Ibid, 2017c: 12,14,16). Moving the resilience debate forward sentiment analysis is a platform for accessing the everyday realities of individuals and communities who are distressed by drugs. An inspection of the Internet and social media discussion forums ${ }^{14}$ reveals numerous examples of working class people detailing harrowing experiences of family members battling addiction, dealing drugs, victims of violence and losing their lives. Incidentally, the City Council is already exploring the use of social media on tourism and the visitor experience (Ibid, 2017c). Through this method local stakeholders could be more accurately attuned to local people's 'lived experiences' with regards to drugs, more effectively capture the 'public mood' and enable more informed policy interventions. In our view sentiment analysis could represent an important step forward in citizen engagement in accessing and exposing the 'street science' and 'local expertise' that is so invaluable to resilience planning (Fainstein, 2018). We are not suggesting that this is a solution to the drugs problem, this requires a more extensive set of political, policy and planning interventions; rather it is a mechanism for exposing drugs to wider public and professional debate. Problematically, in Belfast thus far the resilience debate has been scripted by established elites, as evidenced by the invitee only event that started the resilience journey, and the prescriptive CRF template. Boland et al (2018) argue that since the city embraces neoliberal place branding this effectively 'closes off' (after Joseph 2013; MacKinnon \& Derickson, 2013; Welsh, 2014) the stigma of the drugs problem from open and informed debate. Belfast is obsessed with image transformation - from the murky shadow of 'the Troubles' to the bright lights of a 'competitive, cultural, and creative' city (Boland, 2014) - so public recognition of the 'chronic stresses' (in terms of health, economy and violence) does not fit the contemporary script of a 'post conflict/violent city' (Shirlow, 2006; Murtagh \& Shirlow, 2012; Murtagh, 2018).

\section{Concluding thoughts}

In conclusion, we return to the research question underpinning this paper: to what extent is the Belfast resilience debate inclusive of the major 'stresses/triggers/threats' that exist within the city? The evidence presented here clearly shows this is not the case. Our focus has been on the conspicuous absence

\footnotetext{
14 Belfast Against Drugs: www.facebook.com/BelfastAgainstDrugs/?hc ref=ARQNxXP53glgDhFUz8RCF8pTaQ9ZaeI0YBFqcx2GAuyO $\underline{\text { KAunaHYQ72aZLyJ0RFtC3iI\&fref }=\mathrm{nf}}$

Concerned Families Against Drugs:

http://cfadardoyne.blogspot.co.uk/;

Sluggerotoole:

https://sluggerotoole.com/2017/04/06/an-insight-into-the-latest-drugs-crisis-in-belfast/

Belfast Forum:

www.belfastforum.co.uk/index.php?topic $=63764.0$

BBC Spotlight Twitter.

mobile.twitter.com/BBCSpotlightNI/status/646054591499476992
} 
of the drugs problem, but other equally important challenges are paramilitary flags, emblems and bonfires (BBC News NI, 2017d; Sharkey, 2018). Therefore, the opportunity to use planning for resilience to improve the lives of poorer working class communities - those sections of society who are in many ways adversely affected by these challenges - is sadly deficient. As to why this is the case there is evidence that drugs are too sensitive to include in local planning debates (Boland et al, 2018). If this is a sign of things to come, then we are concerned that Belfast's resilience journey could degenerate into predictable 'policy conservatism' rather than more optimistic 'radical transformation'. Having said that, the recently appointed (non-local) Resilience Commissioner is on record stating: "I'm excited to be working with Belfast City Council and its partners in the interests of the communities we serve" (Long cited in Eichler, 2018). Whilst this may well be an expected platitude, it is also possible that maybe the future trajectory of the Resilience Strategy will change to genuinely recognise and reflect the as yet undetermined suffering and stress of those ordinary people she, and others, are in office to assist, protect and serve.

This paper began by highlighting Belfast's exceptionalism, it concludes with some broader contributions to knowledge. Firstly, we have presented a unique case study interrogating how resilience is 'interpreted and deployed' (after Kythreotis \& Bristow, 2017). Secondly, we are impressed by criticisms directed at the (neoliberal) concept of resilience; however, we also note its

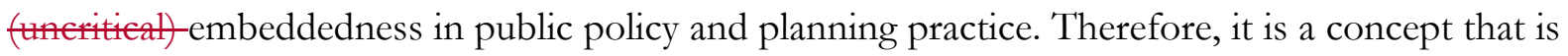
here to stay so we end this paper with some recommendations on how to improve its impact on those most marginalised. Crucially, based on the theoretical engagement and analysis of Belfast we are unconvinced that resilience is a 'promising concept' for planning theory and practice as there is little 'resistance to normality'; this is certainly the case with respect to the drugs problem and is repeated in the other UK 100RC cities (see Bristol City Council, 2016; Greater Manchester Combined Authority, 2017; London Resilience Partnership 2013; Resilient Glasgow, 2016). Taking this into consideration, the key message to emerge from this study is this: it is vitally important that city resilience debates capture as full a range of 'chronic stresses' affecting citizens as possible. As noted by Kaika (2017: 95) there is a "need to incorporate social processes...into future methodology design and policy practices for resilience building”. Failure to recognise and then address systemic social stresses, in this case drugs, is inherently problematic and raises serious questions over the public good in resilience planning. Local stakeholders must therefore listen more widely and carefully to those silent citizens, for example through planning technologies, respect their difficulties and devise resilience plans accordingly. This would necessitate democratising the planning process so that genuine needs are met and the lives of ordinary people are improved. The value of the sentiment 
platform lies in its ability to highlight issues that really matter, issues that planners are guilty of ignoring, afraid to confront and not bringing to the forefront of local debate. A sentiment tool can underscore these problems on the ground and represents an opportunity for planners to enhance the impact of the profession with regards to city resilience. Finally, building on this study new insights are required into other unidentified or sidelined resilience challenges beyond those set out by 100RC and host cities. This is as a task for future research within the planning academe.

\section{References:}

Abramsky, J. \& Drew, S. (2014) Changes to National Accounts: Inclusion of Illegal Drugs and Prostitution in the UK National Accounts. London: Office for National Statistics. Amin, A. (2013) 'Surviving the turbulent future'. Environment and Planning D, 31: 140-156.

Arafah, Y. \& Winarso, H. (2017) 'Redefining smart city concept with resilience approach'. IOP Conf. Series: Earth and Environmental Science. 70: 1-13.

Barry, J. (2017) 'Northern Ireland: hardening borders and hardening attitudes'. Soundings, 66: 4854.

Beilin, R. \& Wilkinson, C. (2015) 'Introduction: Governing for urban resilience'. Urban Studies. 52(7): 1205-1217.

BBC News NI (2017a) ‘Tramadol re-classification call after drugs death'. Accessed via: www.bbc.co.uk/news/uk-northern-ireland-39406068

BBC News NI (2017b) 'North Belfast: UVF criminality targeted in police raids'. Accessed via: www.bbc.co.uk/news/uk-northern-ireland-41240743

BBC News NI (2017c) 'Colin Horner murder linked to UDA tensions, court told'. Accessed via: www.bbc.co.uk/news/uk-northern-ireland-40328605

BBC News NI (2017d) 'Protest against flags in mixed estates in south Belfast'. Accessed via: www.bbc.co.uk/news/uk-northern-ireland-40391901

BBC News NI (2018) “158 security-related deaths’ since Good Friday Agreement’. Accessed via: www.bbc.co.uk/news/uk-northern-ireland-43862294

BBC News NI (2018) 'Getting heroin in Belfast as 'easy' as cigarettes'. Accessed via: www.bbc.co.uk/news/uk-northern-ireland-45102615

BBC News Scotland (2018) 'Drug users in Scotland 'consume most cocaine' in one session'. Accessed via: www.bbc.co.uk/news/uk-scotland-44048083

Beatty, C. \& Fothergill, S. (1998) 'Registered and Hidden Unemployment in the UK Coalfields'. In Lawless, P., Hart, M. \& Hardy, S. (Eds.) Unemployment and Social Exclusion. Landscapes of Labour Inequality. London: Jessica Kingsley: 116-140. 
Beatty, C. \& Fothergill, S. (2002) 'Hidden Unemployment Among Men: A Case Study'. Regional Studies, 36(8): 811-823.

Beatty, C., Fothergill, S. \& Gore, T. (2017) The Real Level of Unemployment 2017. Centre for Regional Economic and Social Research: Sheffield Hallam University.

Belfast City Council (2014) 'New anti-drugs campaign aims to hit home with communities'. Accessed via: www.belfastcity.gov.uk/News/News-33812.aspx

Belfast City Council (2015) The Belfast Conversation. Summary Report. Belfast: Belfast City Council.

Belfast City Council (2017a) The Belfast Agenda: Your future city. A draft for consultation. Belfast: Belfast City Council.

Belfast City Council (2017b) Local Development Plan 2020-2035. Preferred Options Paper. Belfast: Belfast City Council.

Belfast City Council (2017c) Belfast Smart Cities Framework 2017-2021. Belfast: Belfast City Council.

Belfast Telegraph (2015) 'Provos murdered Kevin McGuigan in a row over proceeds from the Northern Bank robbery'. Accessed via: www.belfasttelegraph.co.uk/news/northern-ireland/provos-murdered-kevin-mcguiganin-a-row-over-proceeds-from-the-northern-bank-robbery-31542211.html

Belfast Telegraph (2016a) “This is payback for Jock Davison’ - IRA hitman Kevin McGuigan killed in a hail of bullets at his Belfast home'. Accessed via: www.belfasttelegraph.co.uk/news/northern-ireland/this-is-payback-for-jock-davison-irahitman-kevin-mcguigan-killed-in-a-hail-of-bullets-at-his-belfast-home-31448284.html

Belfast Telegraph (2016b) 'Associates of slain UDA boss John Boreland vow to kill thug they believe pulled trigger'. Accessed via:

www.belfasttelegraph.co.uk/news/northern-ireland/associates-of-slain-uda-boss-johnboreland-vow-to-kill-thug-they-believe-pulled-trigger-34964662.html

Belfast Telegraph (2018a) 'PSNI brand dissident republican group 'drug dealers' after it encourages attacks on police'. Accessed via: www.belfasttelegraph.co.uk/news/northernireland/psni-brand-dissident-republican-group-drug-dealers-after-it-encourages-attackson-police-37413079.html

Belfast Telegraph (2018b) 'Dissident group threatening drug dealers 'have lion's share of the drugs market' says UUP's Doug Beattie'. Accessed via: www.belfasttelegraph.co.uk/news/northern-ireland/dissident-group-threatening-drugdealers-have-lions-share-of-the-drugs-market-says-uups-doug-beattie-36803061.html 
Bell, J. (2016) “Brilliant loyalist groups' keeping drugs off Belfast streets, says UDA boss Stitt'. Belfast Telegraph. Accessed via: www.belfasttelegraph.co.uk/news/northern-ireland/brilliant-loyalist-groups-keepingdrugs-off-belfast-streets-says-uda-boss-stitt-35149458.html

Béné, C., Godfrey-Wood, R., Newsham, A. \& Davies, M. (2012) Resilience: New utopia or new tyranny? - Reflection about the potentials and limits of the concept of resilience in relation to vulnerability reduction programmes. IDS Working Paper 405, Brighton: Institute of Development Studies.

Béné, C., Mehta, L., McGranahan, G., Cannon, T., Gupte, J. \& Tanner, T. (2018) 'Resilience as a policy narrative: potentials and limits in the context of urban planning'. Climate and Development, 10(2): 116-133.

Boland, P. (2014) 'Neoliberal competitiveness and spatial planning: the 'path to economic nirvana' or a 'post-political strategy' and 'dangerous obsession'?' Environment and Planning A, 46(4): 770-787.

Boland, P., Murtagh, B. and Shirlow, P. (2016) 'Fashioning a city of culture: 'life and place changing' or '12 month party'?' International Journal of Cultural Policy: http://dx.doi.org/10.1080/10286632.2016.1231181

Boland, P., Brontë, J. \& Muir, J. (2017) 'On the Waterfront: the politics of public benefit in an era of neoliberal urbanism'. Cities, 61: 117-128.

Boland, P., Fox-Rogers, L., McKay, S. \& Murtagh, B. (2018) 'Illegal geographies and spatial planning: developing a dialogue on drugs'. Territory, Politics, Governance: DOI: $10.1080 / 21622671.2018 .1503092$

Braden, M. et al. (2011) 'Users, carers and professionals experiences of treatment and care for heroin dependency: Implications for practice. A preliminary study'. Journal of Substance Abuse, 16(6): 452-463.

Brenner, N. \& Theodore, N. (2002) 'Cities and the Geographies of "Actually Existing Neoliberalism"”. Antipode, 34(3): 349-379.

Bristol City Council (2016) Bristol Resilience Strategy. Bristol: Bristol City Council.

Bristow, G. (2010a) 'Resilient regions: re-'place'ing regional competitiveness'. Cambridge Journal of Regions, Economy and Society, 3(1): 153-167.

Bristow, G. (2010b) Critical Reflections on Regional Competitiveness. London: Routledge.

Chandrasekaran, R. \& Vinodhini, G. (2012) 'Sentiment Analysis and Opinion Mining: A Survey'. International Journal of Advanced Research in Computer Science and Software Engineering, 2(6): 282-292. 
Chmutina, K., Lizarralde, G, Dainty, A. \& Bosher, L. (2016) 'Unpacking resilience policy discourse'. Cities, 58: 70-89.

Christopherson, S., Michie, J. \& Tyler, P. (2010) 'Regional resilience: theoretical and empirical perspectives'. Cambridge Journal of Regions, Economy and Society, 3(1): 3-10.

Coaffee, J. \& Clarke, J. (2015) 'On securing the generational challenge of urban resilience'. Town Planning Review, 86(3): 249-255.

Cooke, P. (2017) 'Resilience in ruins: the idea of the 'arrested dialectic' in art and after resilience's failures'. European Planning Studies, 25(1): 48-66.

Cooper, K. (2017) 'The Sound of Silence'. The Planner. Accessed via: www.theplanner.co.uk/features/the-sound-of-silence

Crang, M. \& Graham, S. (2007) 'SENTIENT CITIES Ambient intelligence and the politics of urban space'. Information, Communication \& Society, 10(6): 789-817.

Davoudi, S. (2012) 'Resilience: A Bridging Concept or a Dead End?' Planning Theory and Practice, 13(2): 299-333.

Dawley, S., Pike, A. \& Tomaney, J. (2010) ‘Towards the Resilient Region?’ Local Economy, 25(8): 650-667.

Dawson, G. (2017) 'I was shot in the knee as a punishment'. Victoria Derbyshire Programme: BBC News. Accessed via: www.bbc.co.uk/news/uk-42014557

Deal, B., Pan, H., Pallathucheril, V. \& Fulton, G. (2017) 'Urban Resilience and Planning Support Systems: 'The Need for Sentience'. Journal of Urban Technology, 24(1): 29-45.

Department of Health (2018) Statistics from the Northern Ireland Substance Misuse Database: 1 April 2016 - 31 March 2017. Belfast: Information Analysis Directorate.

Derry Journal (2009) 'Only way to eradicate drugs scourge is to remove the dealers'. Accessed via: www.derryjournal.com/news/only-way-to-eradicate-drugs-scourge-is-to-remove-thedealers-1-2139827

Desouza, K. \& Flanery, T. (2013) 'Designing, planning, and managing resilient cities: A conceptual framework'. Cities, 35: 89-99.

Dooley, S. (2018) Meth and Madness in Mexico. Aired Thursday $29^{\text {th }}$ March on W HD channel.

Eichler, W. (2018) 'Belfast appoints resilience commissioner'. Accessed via: www.localgov.co.uk/Belfast-appoints-resilience-commissioner/45098

Fainstein, S. (2015) 'Resilience and Justice'. International Journal of Urban and Regional Research, 39(1): 157-167.

Fainstein, S. (2018) 'Resilience and justice: planning for New York City'. Urban Geography, 39(8): 1268-1275. 
Fitzmaurice, M. (2017) 'Leaflet threatening 'drug dealers' circulated in North Belfast'. Accessed via:

www.belfastlive.co.uk/news/belfast-news/leaflet-threatening-drug-dealers-circulated$\underline{13187740}$

Florida, R. (2014) 'The Creative Class and Economic Development'. Economic Development Quarterly, 28(3): 196-205.

Folke, C. (2006) 'Resilience: The emergence of a perspective for social-ecological systems analyses'. Global Environmental Change, 16(3): 253-267.

Folke, C., Carpenter, S., Walker, B., Scheffer, M., Chapin, T. \& Rockström, J. (2010) 'Resilience Thinking: Integrating Resilience, Adaptability and Transformability'. Ecology and Society, 15(4): 20.

Gillard, R. (2016) 'Questioning the diffusion of resilience discourses in pursuit of transformational change'. Global Environmental Politics, 16, 13-20.

Goldstein, B. et al. (2015) 'Narrating Resilience: Transforming Cities through Collaborative Storytelling'. Urban Studies. 52(7): 1285-1303.

Goldstein, B., Chase, C., Frankel-Goldwater, L, Osborne-Gowey, J., Risien, J. \& Schweizer, S. (2018) Transformative Learning Networks: Guidelines and Insights for Netweavers. Boulder: University of Colorado. Accessed via:

www.researchgate.net/publication/320583177_Transformative_Learning_Networks_Gu idelines_and_Insights_for_Netweavers

Grossi, G. \& Pianezzi, D. (2017) 'Smart cities: Utopia or neoliberal ideology?' Cities, 69: 79-85.

Greater Manchester Combined Authority (2017) Agenda-Setting Workshop Summary Report. Manchester: Greater Manchester Combined Authority.

Hall, T. (2012) 'Geographies of the illicit: Globalization and organized crime'. Progress in Human Geography, 37(3): 366-385.

Hayes, B. \& McAllister, I. (2005) 'Public Support for Political Violence and Paramilitarism in Northern Ireland and the Republic of Ireland'. Terrorism and Political Violence, 17: $599-617$.

Holling, C. (1996) 'Engineering versus ecological resilience'. In Schulze, P. (Ed.) Engineering within Ecological Constraints, Washington: National Academy Press: 31-44.

Holling, C. (2001) 'Understanding the complexity of economic, ecological and social systems'. Ecosystems, 4: 390-405.

Hudson, R. (2010) 'Resilient regions in an uncertain world: wishful thinking or practical reality?' Cambridge Journal of Regions, Economy and Society, 3(1): 11-25. 
Hudson, R. (2014) 'Thinking through the relationships between legal and illegal activities and economies: spaces, flows and pathways'. Journal of Economic Geography, 14(4): 775795.

Johnson, G. (2012) The Cartel: The Inside Story of Britain's Biggest Drugs Gang. London: Mainstream Publishing. Kindle edition.

Joseph, J. (2013) 'Resilience as embedded neoliberalism: a governmentality approach'. Resilience, $1(1): 38-52$.

Kaika, M. (2017) “Don't call me resilient again!': the New Urban Agenda as immunology ... or ... what happens when communities refuse to be vaccinated with 'smart cities' and indicators'. Environment \& Urbanization, 29(1): 89-102.

Kakderi, C. \& Tasopoulou, A. (2017) 'Regional economic resilience: the role of national and regional policies'. European Planning Studies, 25(8): 1435-1453.

Kearney, V. (2018) 'Loyalist paramilitary groups 'to support rule of law". BBC News NI. Accessed via: www.bbc.co.uk/news/uk-northern-ireland-43698164

Kitchin, R. (2014) 'The real-time city? Big data and smart urbanism'. GeoJournal, 79: 1-14.

Kythreotis, A. \& Bristow, G. (2017) 'The 'resilience trap': exploring the practical utility of resilience for climate change adaptation in UK city-regions'. Regional Studies, 51(10): 1530-1541.

Leitner, H., Sheppard, E. Webber, S. \& Colven, E. (2018) 'Globalizing urban resilience'. Urban Geography, 39(8): 1276-1284.

Lennon, M. (2017) 'On 'the subject' of planning's public interest'. Planning Theory, 16(2): 150168.

Leonard, V. (2018) 'Drugs blamed for deaths of Belfast friends Kelly Watters and Stuart Robinson'. Belfast Telegraph. Accessed via: www.belfasttelegraph.co.uk/news/northern-ireland/drugs-blamed-for-deaths-of-belfastfriends-kelly-watters-and-stuart-robinson-36487573.html

London Resilience Partnership (2013) London Resilience Strategy. London: London Resilience Partnership.

MacKinnon, D. \& Derickson, K. (2013) 'From resilience to resourcefulness: a critique of resilience policy and activism'. Progress in Human Geography, 37(2): 253-270.

Magee, K. (2016) 'Heroin: Community concern over use of drug in Belfast'. BBC News NI. Accessed via: www.bbc.co.uk/news/uk-northern-ireland-35556571

Maguire, T. (2017) 'An insight into the latest drugs crisis in Belfast...' Accessed via: https://sluggerotoole.com/2017/04/06/an-insight-into-the-latest-drugs-crisis-inbelfast/ 
Martin, R. (2012) 'Regional economic resilience, hysteresis and recessionary shocks'. Journal of Economic Geography, 12(1): 1-32.

Martin, R. \& Sunley, P. (2015) 'On the notion of regional economic resilience: conceptualization and explanation'. Journal of Economic Geography, 15(1): 1-42.

Massaro, V. (2015) 'The Intimate Entrenchment of Philadelphia's Drug War'. Territory, Politics, Governance, 3(4): 369-386.

McDonald, A. (2016) 'Court hears Belfast in grip of heroin epidemic as Mexican drug cartels attempt to smuggle in drug'. Accessed via:

www.belfasttelegraph.co.uk/news/northern-ireland/court-hears-belfast-in-grip-ofheroin-epidemic-as-mexican-drug-cartels-attempt-to-smuggle-in-drug-35245518.html

McDonald, H. (2013) 'Republican dissidents kill two in Northern Ireland'. Accessed via: www.theguardian.com/uk-news/2013/oct/10/republican-dissidents-kill-two-northernireland

McElrath, K. (2009) 'Drug use and drug markets in the context of political conflict: The case of Northern Ireland'. Addiction Research and Theory, 12(6): 577-590.

McEvoy, K., McElrath, K. \& Higgins, K. (1998) 'Does Ulster still say no? Drugs, politics, and propaganda in Northern Ireland'. Journal of Drug Issues, 28(1): 127-154.

McHugh, M. (2018) 'Drugs seized by police probing dissident republican terrorism'. Accessed via: www.belfastlive.co.uk/news/belfast-news/drugs-seized-police-probing-dissident$\underline{15083545}$

McLaughlin, D., McKenna, H., Leslie, J., Moore K. \& Robinson, J. (2006) 'Illicit drug users in Northern Ireland: perceptions and experiences of health and social care professionals'. Journal of Psychiatric and Mental Health Nursing, 13: 682-686.

McNeilly, C. (2017) 'Northern Ireland youth worker on a mission to help traumatised victims'. The Belfast Telegraph. Accessed via: www.belfasttelegraph.co.uk/news/northern-ireland/northern-ireland-youth-worker-ona-mission-to-help-traumatised-victims-36024768.html

Mehmood, A. (2016) 'Of resilient places: planning for urban resilience'. European Planning Studies, 24(2): 407-419.

Meerow, S. \& Newell, J. (2016) 'Urban resilience for whom, what, when, where, and why?' Urban Geography, DOI: 10.1080/02723638.2016.1206395

Meerow, S., Newell, J. \& Stults, M. (2016) 'Defining urban resilience: a review'. Landscape and Urban Planning, 147: 38-49.

Monaghan, J. (2015) 'Who are Action Against Drugs?’ Accessed via: 
www.irishnews.com/news/2015/08/21/news/who-are-action-against-drugs--235967/

Monaghan, R. (2004) “An imperfect peace': paramilitary 'punishments' in Northern Ireland'. Terrorism and Political Violence, 16(3): 439-461.

Monaghan, R. \& McLaughlin, S. (2006) 'Informal justice in the city'. Space and Polity, 10(2): 171186.

Moraci, F., Errigo, M., Fazia, C., Burgio, G. \& Foresta, S. (2018) 'Making Less Vulnerable Cities: Resilience as New Paradigm of Smart Planning'. Sustainability, 10(755): 1-18.

Murtagh, P. (2018) 'Contested Space, Peacebuilding and the Post-conflict City'. Parliamentary Affairs, 71, 438-460.

Murtagh, B. \& Shirlow, P. (2012) 'Devolution and the politics of development in Northern'. Environment and Planning C, 30: 30-61.

Nolan, P. (2018) The cruel peace: killings in Northern Ireland since the Good Friday Agreement. Accessed via:

www.thedetail.tv/articles/the-cruel-peace-killings-in-northern-ireland-since-the-goodfriday-agreement

Northern Ireland Statistics and Research Agency (NISRA) (2017) Drug Related and Drug Misuse Deaths 2006-2016. Accessed via:

www.nisra.gov.uk/publications/drug-related-and-drug-misuse-deaths-2006-2016

Northern Ireland Statistics and Research Agency (NISRA) (2018) Northern Ireland Labour Market Report, July 2018. Belfast: NISRA.

Office for National Statistics (ONS) (2018) Regional labour market statistics in the UK: July 2018. London: ONS.

O’Neill, S. (2017) 'UTV lifts the lid on Northern Ireland's prescription addiction'. UTV News website. Accessed via:

www.itv.com/news/utv/2017-04-25/northern-irelands-prescription-addiction-revealed/

Organised Crime Task Force (OCTF) (2018) Annual Report \& Threat Assessment 2017.

Organised Crime in Northern Ireland. Belfast: Department of Justice.

Peck, J. \& Tickell, A. (2002) 'Neoliberalizing space’. Antipode, 34(3): 380-404.

Pike, A., Dawley, S. \& Tomaney, J. (2010) 'Resilience, adaptation and adaptability'. Cambridge Journal of Regions, Economy and Society, 5(3): 59-70.

Pizzo, B. (2015) 'Problematizing resilience: Implications for planning theory and practice'. Cities, 43: 133-140.

Police Service of Northern Ireland (PSNI) (2017) Police Recorded Drug Seizures and Arrests in Northern Ireland: Monthly Update to 30 September 2017. Belfast: PSNI. 
Porter, L. \& Davoudi, S. (2012) 'The Politics of Resilience for Planning: A Cautionary Note'. Planning Theory and Practice, 13(2): 329-333.

Pratt, A. (2017) 'Beyond resilience: learning from the cultural economy'. European Planning Studies, 25(1): 127-139.

Resilient Glasgow (2016) Our Resilient Glasgow. A City Strategy: Glasgow: Glasgow City Council.

Scott, S. (2018) 'Councillor calls for meeting after six possible drugs related deaths in Belfast'. Belfast Live. Accessed via: www.belfastlive.co.uk/news/belfast-news/councillor-calls-meeting-after-six-14195508

Sellberg, M., Ryan, P., Borgstrom, S., Norstrom, A. \& Peterson, G (2018) 'From resilience thinking to Resilience Planning: Lessons from practice'. Journal of Environmental Management, 217: 906-918.

Sharkey, K. (2018) 'Belfast residents 'frustrated' over bonfire site'. Accessed via: www.bbc.co.uk/news/uk-northern-ireland-43908430

Shaw, K. (2012) 'Reframing Resilience': Challenges for Planning Theory and Practice'. Planning Theory and Practice, 13(2): 308-312.

Shaw, K. \& Maythorne, L. (2012) 'Managing for local resilience: towards a strategic approach'. Public Policy and Administration, 28(1): 43-65.

Shepard, M. (2009) 'Sentient City Survival Kit: Archaeology of the Near Future'. Proceedings of the Digital Arts and Culture Conference, University of California, Irvine. Accessed via: https://escholarship.org/uc/item/4zp0c4x2

Silke, A. (1998) 'The Lords of Discipline: The Methods and Motives of Paramilitary Vigilantism in Northern Ireland'. Low Intensity Conflict and Law Enforcement, 7(2): 121-156.

Silke, A. (2000) 'Drink, Drugs, and Rock'n'Roll: Financing Loyalist Terrorism in Northern Ireland - Part Two'. Studies in Conflict and Terrorism, 23(2):107-127.

Simmie, J. \& Martin, R. (2010) 'The economic resilience of regions: towards an evolutionary approach'. Cambridge Journal of Regions, Economy and Society, 3(1): 27-43.

Sky News (2018) 'Cocaine can be delivered quicker than pizza across UK, survey says'. Accessed via: $\quad$ https://news.sky.com/story/cocaine-is-delivered-quicker-than-pizza-survey-says$\underline{11364608}$

Souza, M. L. de (2005) 'Urban planning in an age of fear: The case of Rio de Janeiro'. International Development Planning Review, 27(1): 1-19.

The Irish News (2017) 'Funeral of Carrickfergus feud victim to take place'. Accessed via: 
www.irishnews.com/news/2017/03/22/news/funeral-of-feud-victim-to-take-place$\underline{971915 /}$

Thrift, N. (2014) 'The 'sentient' city and what it may portend'. Big Data and Society, 1(1): 1-24.

United Nations Office on Drugs and Crime (UNODC) (2018) World Drug Report 2018. Accessed via: www.unodc.org/wdr2018/

UTV News (2018) 'Seven drug deaths investigated in Belfast in last three weeks'. Accessed via: www.itv.com/news/utv/2018-01-23/seven-drug-deaths-investigated-in-belfast-in-lastthree-weeks/

Vale, L. (2014) 'The politics of resilient cities: whose resilience and whose city?' Building Research and Information, 42(2): 191-201.

Vinodhini, G. \& Chandrasekaran, R. (2012) 'Sentiment Analysis and Opinion Mining: A Survey'. International Journal of Advanced Research in Computer Science and Software Engineering, 2(6): 282-292.

Weichselgartner, J. \& Kelman, I. (2015) 'Geographies of resilience: Challenges and opportunities of a descriptive concept'. Progress in Human Geography, 39(3): 249-267.

Welsh, M. (2014) 'Resilience and responsibility: governing uncertainty in a complex world'. The Geographical Journal, 180(1): 15-26.

Wiig, A. \& Wyly, E. (2016) 'Thinking through the politics of the smart city'. Urban Geography, 37(4); 485-493.

Wilkinson, C. (2012) 'Urban Resilience: What Does it Mean in Planning Practice?' Planning Theory and Practice, 13(2): 319-324.

Wilson, A., Tewdwr-Jones, M. \& Comber, R. (2017) 'Urban planning, public participation and digital technology: App development as a method of generating citizen involvement in local planning processes'. Environment and Planning B, 0(0) 1-17.

Wilson, D. \& Jonas, A. (2018) 'Urban resilience: an urban political movement'. Urban Geography, 39(8): 1265-1267

Wilson, R. (2016) Northern Ireland Peace Monitoring Report. Number Four. Belfast: Community Relations Council.

Woodruff, S. Meerow, S., Stults, M. \& Wilkins, C. (2018) 'Adaptation to Resilience Planning: Alternative Pathways to Prepare for Climate Change'. Journal of Planning Education and Research, 1-12: DOI: 10.1177/0739456X18801057

Yu L. et al (2018) 'Improving early prediction of academic failure using sentiment analysis on selfevaluated comments'. Journal Computer Assisted Learning, 1-8: https://doi.org/10.1111/jcal.12247 